\title{
An empirical study on Antecedents and Consequences of job stress in different organizations of Bahawalpur
}

Aqurat-ul-ain

Department of Management Sciences, The Islamia University of Bahawalpur, Pakistan

Saeed Iqbal

Department of Management Sciences, The Islamia University of Bahawalpur, Pakistan

\section{Um-e-Aiman}

Department of Management Sciences, The Islamia University of Bahawalpur, Pakistan

\section{Shakiba khawar}

Department of Management Sciences, The Islamia University of Bahawalpur, Pakistan

\section{Muhammad Rizwan}

Lecturer, Department of Management Sciences

The Islamia University of Bahawalpur, Pakistan

E-mail: rizwan.arshad@iub.edu.pk

DOI:10.5296/ ijld.v4i2.6096 URL: http://dx.doi.org/10.5296/ ijld.v4i2.6096

\begin{abstract}
One of the largest threats that modern technological world facing now days is job stress. It's the foundation reason behind several issues, negatively touching associate degree staff operating in multiple ways in which, that all gather to make major problems. Folks stepping out of their homes daily to earn area unit all on job and no matter hurdles they face in their work produce stress in their jobs. The fundamental purpose of this analysis is to work out what job stress is, however it arises during an operating surroundings and what area unit its outcomes.

This study not solely indicate the key causes of job stress i.e. role conflict and role ambiguity however additionally analyze the consequence of job stress, move negative impacts on associate degree employee's job satisfaction, organization commitment,
\end{abstract}


organization communication, job performance and result in accrued turnover intentions. The findings of this analysis are utilized to boost operating conditions associate degreed avoid all such factors that will result in job stress and ultimately reduced quality and performance of a worker.

Some public and private organizations situated within BWP city were selected and a survey was conducted to determine how employees feel at work in different situations. A questionnaire was asked to be filled. Participation of every person was voluntary. A total of 200 questionnaires were distributed, and 150 were selected as appropriate, giving a total of $75 \%$ feedback. Remaining questionnaires were rejected as they were not filled correctly. Data collected through questionnaire was summed up and analyzed through SPSS, by applying suitable methodologies.

Keywords: Job stress, job performance, role conflict, role ambiguity, organization commitment, organization communication, turnover intentions.

\section{Introduction}

Job stress has gained significant attention in past organization behavior research. The word "stress" introduced in the field of physics and was transferred into consciousness. Basically, the idea is that human beings try to resist external forces affecting them. Job stress can be stated as an employee's cognizance or sensitivity of personal dysfunction that is caused by unhealthy conditions or events in the workplace, and the employee's psychological and physiological reactions due to these painful, adverse dangers in the employee's immediate working environment.

Stress at work may be a well-known development which will have variable impacts, and have an effect on staff otherwise, in numerous work conditions. If we tend to study job stress in numerous frameworks it'll give deeper understanding of this whole development and tell North American nation to scale back its harmful effects on workers' productivity, satisfaction and their commitment. Achieving advantages of booming work place is nothing however AN art of coping with stress. Some researches thinks that manners, vogue and means of making an attempt a haul of men and girls in their jobs fluctuate at extreme levels whereas others validate that there's nothing insignificant between them. The workers encounter role stress after they square measure appointed to try and do work quite their capability. Sager, employing a causative modal, represented 3 antecedents to job stress.

(1) Sales manager's consideration

(2) Role ambiguity

(3) Role conflict.

He also examined three consequences;

(1) Organizational commitment 
(2) Job satisfaction

(3) Turnover intention

When sales manager supposing to try to to one thing else than your expectation than it conjointly cause job stress. Rizzo et al. (1970) has outlined role ambiguity as associated with someone World Health Organization lacks clear direction concerning the expectations of his or her role within the job or organization. Rizzo et al. (1970) outlined role conflict as pair in communicated expectations that impose on perceived role performance.

Job stress directly influences job satisfaction, job performance, and Organization commitment and organization communication. Job performance shows the amount of accomplishment of business from the angel of judgment party. Job satisfaction is really however individual feel concerning their jobs and totally different aspects of their job. Organization communication is that the degree to that data concerning job is communicated by a corporation to its members and among the member of organization. Organization commitment shows the employee's attachment to the using organization - particularly, the commitment to the whole organization because the worker perceives it (Morrow, 1993) and therefore the organization's support for the worker (Zaitman-Speiser,2005; bleach,2001).

Job satisfaction is one among the foremost succeeding job results suffering from role stress. Some researchers indicate that role stress (role conflict/ambiguity) has bigger effects on job satisfaction for definite varieties of workers than others. Several analysis results show that job satisfaction has important and negative relation with turnover intentions on an even basis. Recent models of turnover intentions have coupled perceived job stress with turnover intentions through completely different intermediate withdrawal perceptions like job satisfaction and organization commitment.

There are often several causes for low performance in an exceedingly job, like the atmosphere of firm, interaction of colleagues, managerial positions, want for promotions and temperament.

The shocking prices complaints associated

with within the yank economy are calculable at nearly $\$ 300$ billion. There are various findings of negative physical impacts associated with geographical point stress. These outcomes embrace frustration, depression, and varied physical disorders, structure prices as a result of stress have multiplied owing to higher accident levels, lost time, and reduced productivity.

The initiation for multiplied levels of stress within the fashionable work surroundings is superficial 1 from the pressures for modification arising in several organizations. In between high ranks and multi-national corporations the competition level touches sky, in result the expectations

of client conjointly rises, that mechanically desires additional diligence of worker in work. In commission organizations worker work as boundary spanners, in order that they expertise a fitted work surroundings. Once the expectation of a client crosses the boundary, it causes role stress that becomes the explanation to try and do the work with additional output to fulfill all the necessities of the client. The possibility for enhanced levels of stress within modern 
work surroundings is clear from the pressure for amendment occurring in several organizations. In between high rank and multi-national firms the competition level touches skyline result the expectation of client additionally raises, that mechanically desires a lot of exertions of worker in work.

Emotional work causes stress, and will lead to enhanced absence and voluntary turnover. Previous analysis studies on turnover intentions exploitation individual distinction variables have targeted on such demographic characteristics as age, tenure, sex, education level, and family size. The result shows a homogenous negative relationship for age and tenure with turnover intentions, and there's mixed results for sex, education level, and family size with turnover intentions.

\section{Literature Review}

\section{Job Stress}

Job stress will be expressed as associate degree employee's responsiveness or feeling of non-public dysfunction that results from perceived conditions or happenings within the work, and therefore the employee's psychological and physiological reactions because of these uncomfortable, undesirable, threats within the employee's fast work surroundings (Montgomery et al., 1996).Job stress has received predominant attention in past analysis (Fisher, 2001; Bernardi, 1997; clog, 1995; Choo, 1987).Stress doesn't arises directly from the supply of pressure itself, however rather from the perception of that pressure. Job stress is additional of a private reaction and is completely different from general stress because it is additionally organization and job connected, (Montgomery et al., 1996).In the space of job stress, Louis Isadore Kahn and Byosiere (1992) finished that structure analysis has not been involved with structure and social factors which may act as moderators, buffers, or may be as antidotes to fretwhich there's little experimental proof to recommend weakening factors may or might not exist. However, Montgomery et al. (1996) see adverse job stress as dysfunctional and decreasing commitment and productivity. Williams et al. (2001) stressed that short results of job stress have each physiological and behavioral impacts on job performance. Stress will be positive yet once the case offers a chance for a private to feature one thing helpful. It acts as a booster for poor performance. Stress is also negative oncean individual faces social, physical, structure and emotional hurdles. Hobful, (1989) noted that human resource provides basic concept that the kinsmen tend to resist external forces acting upon them, even as do physical materials and bodies. Keinan (1997) argued that in todays world, the idea of stress is wide unfold however polemic, and to be outlined in many ways that. Prolonged stress has been found to be fatal to each the well-being of workers (e.g., anxiety, depression, and health problems) and organizations (e.g., enhanced turnover and leave of absence, reduced motivation and morale, poor quality of service, and blemished reputation) (de sing et al., 2004; Kim, 1996; Noone,2008; Rizwan et al., 2013). These and different harmful effects highlight the necessity to higher perceive and reduce excessive job stress. 


\section{Organization Communication}

Organizational

communication

is outlined because

the degree

to that information concerning job is transmitted by a company to its members and among the members of a company. A study of the analysis on organization processes showed that member satisfaction with organization communication practices has been unheeded. These results show that corporations strengthen their communication channels and processes to strengthen their organization commitment and job performance. It appears that stress and Organization communication are independent variables that don't have an effect on one another. This finding seems to contradict that of Stamper and Johlke (2003) World Health Organization same that events associated with organization communication can be accustomed cut back stress. It seems that stress and organization communication are independent variables that don't have an effect on each other. This finding seems to oppose that of Stamper and Johlke (2003) World Health Organization found that problems associated with organization communication can be accustomed cut back stress. High levels of organization communication bring about to higher levels of organization commitment and job performance. Astonishingly, stress levels weren't found to be connected to either organization communication or job performance. The finding that stress levels weren't slashed by accumulated organization communication and had very little impact on job performance suggests that in several field stress might play a distinct role.

$\mathrm{H} 1$ : There is a negative relationship between organizational communication and job stress.

$\mathrm{H} 2$ : There is a negative relationship between organizational communication and turnover intention.

If Organization communicates more with their employees than it increase the job performance and will decrease the job stress.

\section{Job Satisfaction}

Job satisfaction is represented as merely however folks feel concerning their jobs and totally different characteristics of their jobs. Job satisfaction refers to people's feelings concerning the advantages they need received on the work. Thus, satisfaction is Associate in Nursing outcome of past events.Job satisfaction is outlined because the sense of positive feelings that an individual experiences in reference to the person's job. it had been quantified by 5 things tailored from Schleicher et al. (2004) job satisfaction scale. Job satisfaction is however folks assume \& feel concerning their work place and totally different aspects concerning it. Job satisfaction is all concerning folks behavior that to that extent folks like or dislike their work place. Worker's sense of accomplishment and success at the work place represent job satisfaction. Generally, it's perceived as an instantaneous link to productivity moreover being of staff.

Job satisfaction entails that if somebody perform work activities excellently then his or her efforts ought to be rewarded it's according by Kaliski, (2007) that job satisfaction implies 
happiness and enthusiasm with one's work and it's the key element that leads employee to financial gain promotion, recognition and also the accomplishment of different goals that results in a sense of fulfillment. Job satisfaction has been one among the foremost immediate jobs outcomes stricken by role stress. Some researchers argued that role stress (role conflict/ambiguity) has bigger effects on job satisfaction for specific forms of workers than others. Gender variations are used as a moderator within the relationship between role stress and job satisfaction (Rizwan et al., 2013).

Job satisfaction is Associate in treatment attitudinal variable expressing Associate in nursing employee's overall feeling toward the duty. It has been found to be connected absolutely to positive mood, job involvement, and performance and is especially necessary in technical staff thanks to the competitive edge they bring about. Typical models of turnover fail to explain individual variations. Locke's discrepancy conceptualization of job satisfaction says that Associate in nursing employee's job satisfaction was a function of the match

(or discrepancy) between the employee's wants and what he or she racially has. A person's overall impactive feeling (satisfaction) towards the work has primarily been found to be negatively associated with stress (role ambiguity) Role conflict looks to own a stronger effect on job satisfaction than will role ambiguity. Sager's findings recommend that role conflict directly affects job stress and job satisfaction whereas job satisfaction looks to scale back job stress and intention to go away. Job stress indirectly influences intentions to go away through organization commitment. Ambiguity will have an effect on satisfaction indirectly through role conflict.

H3 There is a negative relationship between job stress and job satisfaction.

H4: There is a positive relationship between job satisfaction and organization commitment.

\section{Organizational Commitment}

Organizational commitment has been outlined as an attachment to or identification with the organization. It can even be seen as an emotional response to a positive appraisal of the work surroundings. Such an emotional feedback is also thought about an attachment, significantly once the individual believes powerfully within the organization's values and goals or demonstrates a robust want to take care of membership within the organization. Career commitment will be expressed because the strength of one's motivation to figure during a chosen career role. It shows one's dedication to a field of labor. Prior analysis has indicated that organization commitment could be a multi-dimensional construct. Organization commitment has been known as a intermediate between job satisfaction and turnover intentions. Staff United Nations agency square measure extremely committed to their organization square measure less probably to go away than staff United Nations agency square measure comparatively uncommitted. 
Specifically, it's foreseen that organization commitment is negatively associated with turnover intentions. Many empirical studies ensure the vital role of organization commitment within the turnover method, and that they usually indicate that an individual's turnover intention is negatively associated with job satisfaction and organization commitment. This relationship is additional supported by variety of studies that establish job satisfaction as an antecedent of organization commitment. As a positive emotive response, it's cheap to assume that job satisfaction would be negatively associated with behavioral intentions to turnover.

H5: There is a negative relationship between job stress and organizational commitment.

\section{Role Ambiguity}

Rizzo et al. (1970) outlined terribly clearly that role ambiguity is said with a private one who is unable to clear his goal in his organization. If an individual lacks the directions to figure in a corporation, then he can face the issues of role ambiguity which is able to finally lead towards job stress. There are many alternative studies conjointly that support this time (Fry et al., 1986; Johnston et al., 1990a; Niemeyeret al., 1990; Sager, 1994). Role ambiguity is said with an individual with un-clear approach because of lack of knowledge (Behrman and Perreault, 1984).

Now a day's fast organization growth and trendy technology is making issues for workers as they notice their self terribly troubled to be capable to deal with this advancement. It is outlined as an absence of clarity regarding expected behavior from employment is troublesome to outline. The common thought behind role ambiguity is that a state of affairs that happens once individuals isn't clear regarding their role. People are frequently getting into in to true wherever there's no doable for complete info. Therefore it's tough to order clear instruction or apply coaching received to a particular scenario. This lack of knowledge might raise the doubt concerning expectations associates with the role. A disagreeable scenario is made once role isn't clear. Job stress is additionally full of job ambiguity. once role expectations aren't clear this example leads towards role conflict that finally produce job stress, as a result of workers don't have any concept that wherever they ought to use their skills. (Beehr and Bhagat, 1985; Rizzo et al., 1970)

When worker is unable to assess the result of his efforts then it causes ambiguity. This example is nice contributor of job stress because it is made by lack of management of a employee (Karasek, 1979). once role necessities aren't clear then it becomes terribly tough for workers to require call concerning their work (Rizzo et al., 1970).Classical structure theory maintains that every role ought to have a selected vary of tasks and areas of responsibility (Weisner, 2003).Sager (1994) projected a positive association among role conflict and role ambiguity since relatively weak associations are found between ambiguity and job satisfaction and alternative attitudinal variables. Job satisfaction has been later job results full of role stress. Ambiguity influence satisfaction ultimately through role conflict. Previous 
researches evidence that role ambiguity and role conflict has main unfavorable effects on frontline employees' self-efficacy or their perspective in their capabilities to with success do job-related tasks. A meta-analysis and several experimental studies also conclude that role conflict and role ambiguity have significant negative effects on employees' job satisfaction.

H6: Role ambiguity has a positive impact on job stress and negative impact on job satisfaction.

H7: Role ambiguity has a negative impact on job performance, Organization commitment and organization communication.

\section{Role Conflict}

Rizzo et al. (1970) role conflict is associate inconsistent communicated expectation that is being obligatory considerably on perceived role performance. Once role of associate worker is related to the degree of inconsistency it's known as role conflict (Miles and Perreault,(1976). Once requests of supervisor and customers don't seem to be matched this known as a typical role conflict. As lack of expertise relating to role information will increase it results in additional role conflict. Role conflict considerations incompatible role expectations. It's outlined as "a conflict" among the role adores or additional standing. Role theory suggests that people commonly behave per their instructed roles and that they stay in line with those roles (Kahn et al., 1964). once resources square measure scarce then staff square measure to be performed multiple roles which will produce job tension and job stress as a result of staff don't seem to be cognizant of their roles (e.g., time or energy). Negative results begin generating once worker role is raised or job demand is raised. Researchers have steered that role conflict is joined to variety of Negative outcomes, together with psychological stress and job discontentedness (Rizzo, House \&Lirtzman, 1970; Schaubroeck, Cotton, \& Jennings, 1989). As antecedently mentioned, once 2 or additional sets of role pressures exist in an individual's work atmosphere and also the obedience with any of those pressures obstructs the action of another, role conflict happens (Kahn et al., 1964). When staff is insecure and lack management then results ar devastating and also the conception of role conflict is formed. Role theory (Kahn et al., 1964) precisely describes the potential role stressors which will cause stress.

Such conflict is said to abstract variations between staff and completely different supervisors relating to the content or importance of needed job tasks. This creates conflict: the commitment to variety of superiors against the individual's values moving to the organization's needs (Kahn and Byosiere, 1992). Researchers have counseled that so as to stop role conflict, organizations ought to perform per the standard structure theory principle of unity of authority, that is, that the worker ought to be supervised byone superior and work per one setup. An organization that cares for its staff should spare them the "cross-fire" 


\section{Macrothink}

International Journal of Learning \& Development

ISSN 2164-4063

2014, Vol. 4, No. 2

of 2 or additional betters World Health Organization have incompatible work directions and expectations. Many studies report direct and positive influences between role conflict and job stress. Additionally to impacting job stress, role conflict is predicted to be a negative influence on job satisfaction and job expectations. Sager's findings recommend that role conflict directly influences job stress and job satisfaction whereas job satisfaction seems to scale back job stress and intention to go away. Sager's findings recommend that role conflict directly impacts job stress and job satisfaction whereas job satisfaction seems to scale back job stress and intention to go away. Role conflict appears to possess a stronger result on job satisfaction than will role ambiguity.

H8: Role conflict has a positive impact on job stress.

H9: Role conflict has a negative impact on organization communication, job performance and job satisfaction.

\section{Turnover Intentions}

It is a scenario of subjective assessment once workers feel that they're going to leave their current leader terribly presently. Once a competent worker resigns, it puts a negative impact on the value of a company. Once work is on emotional basis it creates nerve-wracking operating, and should end in enlarged absence and intentional turnover. Some researches support that job stress effects intention to depart albeit the relation looks to be indirect. Job satisfaction and organization commitment decreases as stress is enhanced. Once there's terribly low commitment and extremely low job satisfaction, it creates propensity to depart. Job stress indirectly influences intentions to depart through organization commitment. Higher job satisfaction and commitment to the organization area unit related to lower propensity to depart. Satisfaction and commitment has invariably rumored a negative relationship to intent to depart and turnover.

H10: There is an indirect and negative relationship between job stress and turnover intentions, higher job stress lead to higher turnover intentions. 


\section{Figure 1:}

\section{Proposed Model of Research}

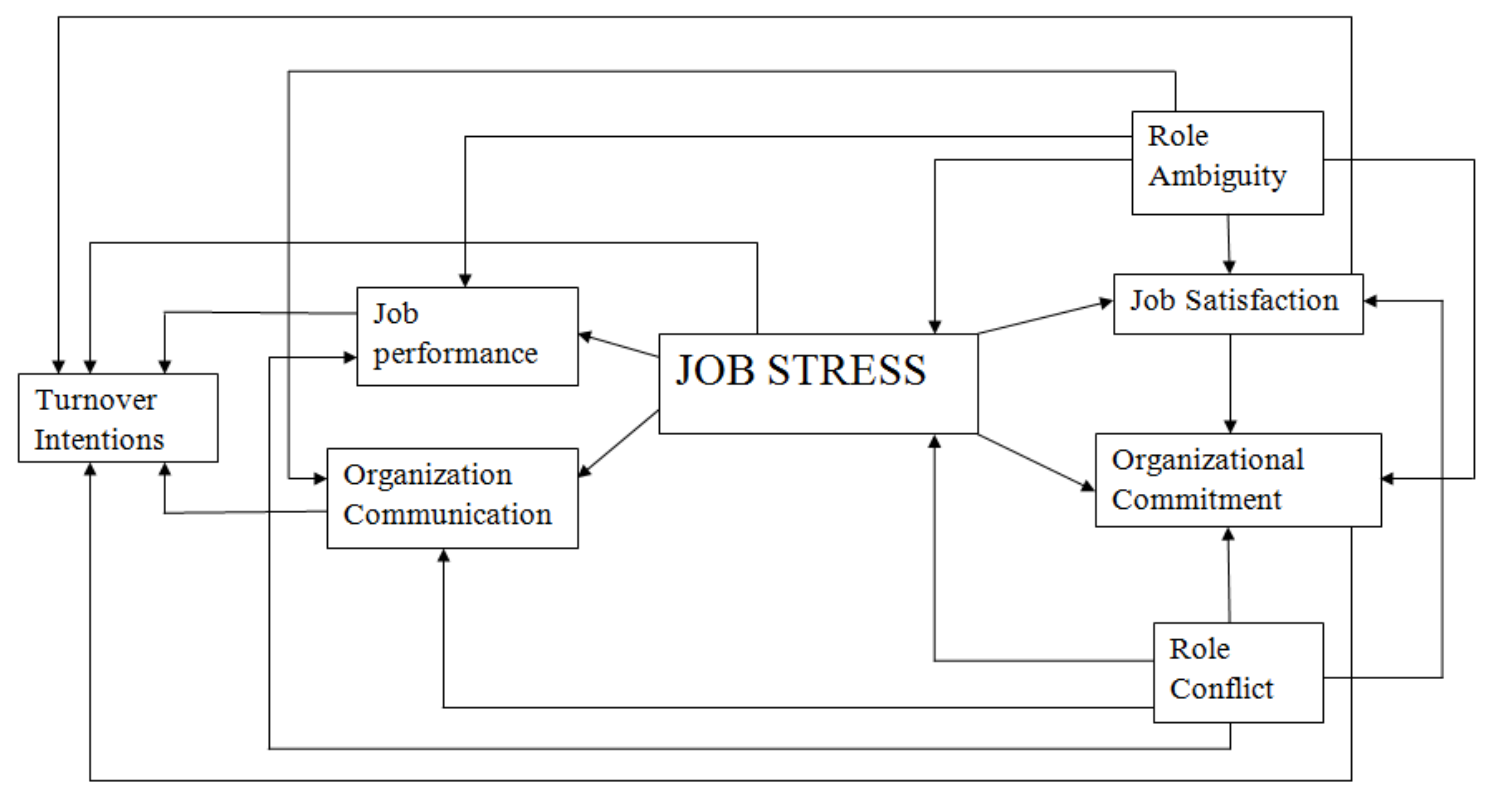

\section{Research Methodology:}

The present research is descriptive in it nature. Descriptive research can be explained as describing something, particular situation and any phenomenon. Descriptive researches are that explain the existing circumstances instead of interpreting and making judgment. The main objective of the research is verification of the developed hypothesis that reflects the current situation. This type of research provides information about the current scenario.

\section{Sample/ data:}

In order to collect the data for understanding the situation about the job stress, a sample of 150 respondents were asked to participate in a self-administered questionnaire. The current study utilizes a non-probability sampling technique that is convenience sampling. Convenience sampling is sampling techniques that obtains and collect the relevant information from the sample or the unit of study that are conveniently available (Zikmund, 1997).Convenience sampling is normally used for collecting a large number of completed surveys speedily and economically (Lym et al.2010).

It has ensured that the sample members posses two main qualifications to participate in the self administered survey. First the sample member should be an employee, and secondly he/she must have been in certain circumstances where they have faced job stress.

We selected these sample members from different organizations of Bahawalpur. Following 
were targeted to collect the sample data like working professionals (Nishat linen), The Islamia University of Bahawalpur, Muslim commercial bank, Habib bank Ltd, Bank of Punjab, National Bank of Pakistan, franchises of Ufone and Zong.

\section{Instrument and measure}

There are two main purposes of survey instrument, first is to examine the relationship of various variables of job stress. Second, we collect information about different attributes of the respondent which are use to know the trend in different categories in job stress. The survey instrument contains two sections. It includes different personal demographic variables. This section will obtain the respondent's information about gender, age, income, education, status and the company.The latent variables that are important in the current study include job stress, organizational commitment, job satisfaction, job performance, organization communication, role conflict, role ambiguity and turnover intention. This section of the study is developed based on the past literature and questionnaire. The scales of the study were adopted from the previous literature and revealed studies. The primary variable was job stress having four things and these scales were taken from Cummann et al. (1979). The second variable was role ambiguity having four things and these scales were taken from (Rizzo et al. 1970). The third variable was job satisfaction having 3 things and these scales were taken from Rees (1995) and Young and Cooper (1995). Next variable was role conflict having four things and these scales were taken from Fisher and Gittleson (1983). the opposite variable was organization commitment support having 5 things and these scales were taken from Mowdayet al. (1979). Next variable was organization communication having 5 things and these scales were taken from worth (1995). The opposite variable was turnover intention having 3 things and these scales were taken from Cummann ET al.1979. And therefore the last variable was job performance having 3 things and these scales were taken from (Bowraet al., 2011).

Table1: scales of the study:

\begin{tabular}{|l|l|l|l|}
\hline Sr. \# & Variable & Items & Reference \\
\hline 1 & $\begin{array}{l}\text { Employee } \\
\text { turnover } \\
\text { intention }\end{array}$ & $\begin{array}{l}\text { 1- I will likely actively look for a new job in the } \\
\text { next year. } \\
2-\end{array}$ & $\begin{array}{l}\text { Cummann et } \\
\text { al. (1979) } \\
3-\end{array}$ \\
\hline 2 & & I probably look for a new job in the next year. \\
& & & \\
\hline
\end{tabular}




\begin{tabular}{|c|c|c|c|}
\hline & $\begin{array}{l}\text { Organizational } \\
\text { Commitment }\end{array}$ & $\begin{array}{l}\text { great organization to work for. } \\
\text { 2-I feel great loyalty to this organization. } \\
\text { 3-I am proud to tell others that I am part of this } \\
\text { organization. } \\
\text { 4- I talk up this organization to my friends as a great } \\
\text { Organization to work for. } \\
\text { 5-It would take very little chance in my present } \\
\text { circumstances to cause me to leave }\end{array}$ & $\begin{array}{l}\text { Porter et al. } \\
(1974)\end{array}$ \\
\hline 3 & Job Satisfaction & $\begin{array}{l}\text { 1-Most days, I am enthusiastic about my job. } \\
\text { 2-I find enjoyment in my job. } \\
\text { 3-I am fairly well satisfied with my job. }\end{array}$ & $\begin{array}{l}\text { Rees,(1995) } \\
\text { Young and } \\
\text { cooper,(1995) }\end{array}$ \\
\hline 4 & Job stress & $\begin{array}{l}\text { 1) I do not have enough time to get everything done } \\
\text { on my job. } \\
\text { 2) I face difficulty getting supplies I need on my job. } \\
\text { 3) I do not have adequate equipment to do my job. } \\
\text { 4) I do not have enough support services to do my } \\
\text { job. }\end{array}$ & $\begin{array}{l}\text { Cohen et al. } \\
\text { (1983) }\end{array}$ \\
\hline 5 & $\begin{array}{l}\text { Organization } \\
\text { communication }\end{array}$ & $\begin{array}{l}\text { 1) My supervisor/upper management let us know } \\
\text { about the changes that are coming up. } \\
\text { 2) My supervisor/upper management let us know } \\
\text { which areas of my performance are weak. } \\
\text { 3) My supervisor/upper management discuss with me } \\
\text { how to get additional training. } \\
\text { 4) When I ask a question my supervisor/upper } \\
\text { management does their best to get me an answer. } \\
\text { 5) My supervisor/upper management discuss about } \\
\text { my interest outside the organization. }\end{array}$ & $\begin{array}{l}\text { Price } \\
(1995)\end{array}$ \\
\hline
\end{tabular}




\begin{tabular}{|c|c|c|c|}
\hline 6 & Role ambiguity & $\begin{array}{l}\text { 1) I feel secure about how much authority I have. } \\
\text { 2) Clear planned goal and objectives for my job. } \\
\text { 3) I know that I have divided my time properly. } \\
\text { 4) I know that what my responsibilities are. } \\
\text { 5) I know that exactly what is expected of me. } \\
\text { 6) Explanation Is clear of what has been done. }\end{array}$ & $\begin{array}{l}\text { A } 6 \text { items scale } \\
\text { adapted from } \\
\text { (Rizzo et al. } \\
\text { 1970) role } \\
\text { ambiguity } \\
\text { scale. }\end{array}$ \\
\hline 7 & Role conflict & $\begin{array}{l}\text { 1) I have to do things that should be done differently. } \\
\text { 2) I receive an assignment without the manpower to } \\
\text { complete it. } \\
\text { 3) I work without or more groups who operate quite } \\
\text { differently. } \\
\text { 4) I have to buck a rule or policy to carry out a } \\
\text { assignment. } \\
\text { 5) I receive incompatible requests from two or more } \\
\text { people. } \\
\text { 6) I do things that are up to be accepted by one person } \\
\text { and not acceptable by other. } \\
\text { 7) I receive an assignment without adequate resources } \\
\text { and material to execute it. }\end{array}$ & $\begin{array}{l}\text { Fisher } \\
\text { And } \\
\text { Gittleson } \\
\text { (1983) }\end{array}$ \\
\hline 8 & $\begin{array}{l}\text { Job } \\
\text { performance }\end{array}$ & $\begin{array}{l}\text { 1) My performance is better than that of my } \\
\text { colleagues with similar qualifications. } \\
\text { 2) I am satisfied with my performance because it is } \\
\text { mostly good. } \\
\text { 3) My performance is better than that of Bankers with } \\
\text { similar qualifications in other Banks. }\end{array}$ & $\begin{array}{l}\text { (Bowra et al., } \\
\text { 2011) }\end{array}$ \\
\hline
\end{tabular}

\section{Procedure:}

The form was distributed among two hundred respondents in Bahawalpur. These respondents square measure chosen supported the factors higher than mentioned. Before giving the form, the aim of study and queries were explained to the respondents in order that they will simply fill the form with relevant responses. A complete of a hundred and fifty questionnaires was chosen. Once collection the finished questionnaires, these 
questionnaires were coded and entered into SPSS sheet for any analysis.

\section{Reliability analysis}

Table 2

Reliability of measuring instrument

\begin{tabular}{|l|l|l|}
\hline Scales & Items & Cronbach alpha \\
\hline Employee turnover intention & 3 & 0.647 \\
Organizational commitment & 5 & 0.533 \\
Job satisfaction & 3 & 0.542 \\
Organization communication & 5 & 0.541 \\
Job stress & 4 & 0.535 \\
Role ambiguity & 4 & 0.541 \\
Role conflict & 4 & 0.551 \\
Job performance & 3 & 0.550 \\
\hline
\end{tabular}

\section{Results and analysis}

Personal and demographic information such as gender, age, income, education and company are presented in the following table.

\begin{tabular}{|l|l|l|l|}
\hline Variables & Category & Frequency & Percentage \\
\hline Gender & Male & 94 & 62.7 \\
Female & 56 & 37.3 \\
\hline Age & $15-20$ years & 26 & 17.3 \\
$20-25$ years & 36 & 24.0 \\
$25-30$ years & 35 & 23.3 \\
& $30-35$ years & 20 & 13.3 \\
\hline
\end{tabular}




\begin{tabular}{|l|l|l|l|}
\hline & $35-40$ years & 19 & 12.7 \\
& Above 40 years & 14 & 9.3 \\
\hline Income(Rs/month) & Below 15000 & 30 & 20.0 \\
& $15000-25000$ & 34 & 22.7 \\
& $25000-35000$ & 26 & 17.3 \\
& $35000-45000$ & 22 & 14.7 \\
& $45000-55000$ & 18 & 12.0 \\
& Above 55000 & 20 & 13.3 \\
\hline \multirow{2}{*}{ Education } & Matriculation & 8 & 5.3 \\
& Inter & 21 & 14.0 \\
& Bachelor & 54 & 36.0 \\
& Master & 46 & 30.7 \\
& MS/M.phill & 14 & 9.3 \\
& PHD & 7 & 4.7 \\
& &
\end{tabular}

\section{Hypothesis testing:}

H1: Job stress effects job performance, job satisfaction, organization communication, organization commitment.

According to the results of the study, the variable has significant negative relationship ( $\beta=-.099),(\beta=-.151),(\beta=-.002),(\beta=-.108)$, with significance value $(p<0.05)$.that means the job performance contribute $9 \%$ to job stress. Job satisfaction contributes $15 \%$ to job stress. Organization communication contributes $.002 \%$ in job stress and organization commitment contributes $.008 \%$ in job stress. Results of current study validate the H1.

H2: Job stress effects TOI.

Results shows that, job stress has insignificant positive relationship with TOI with $(\beta=.120)$ and $(\mathrm{p}>0.05) . \mathrm{H} 2$ is rejected.

H3: Job performance effects TOI.

Results shows that job performance has significant negative relationship with TOI with ( $\beta=$ 


\section{Macrothink \\ International Journal of Learning \& Development \\ ISSN 2164-4063 2014, Vol. 4, No. 2}

$-0.319)$ with $(\mathrm{p}<0.005)$.So H3 is accepted.

H4: job satisfaction effects TOI

The regression analysis results of the study confirm the significant negative relation between job satisfaction and turnover intention with $(\beta=-0.153)$ and $(\mathrm{p}<0.005)$. Job satisfaction contributes $15 \%$ to TOI. Current study validates the $\mathrm{H} 2$.

\section{H5: Organizational commitment effects TOI}

The analysis shows that organizational commitment has insignificant negative relationship with TOI with $(\beta=-.121)$ and $(p>0.05)$. It rejects the H3.

H6: Role ambiguity effects job stress

Regression estimates results shows that the role ambiguity has insignificant positive relationship with job stress with $(\beta=0.076)$ and $(p>0.05)$. The $\mathrm{H} 4$ is rejected.

H7: Role ambiguity effects job performance, organization commitment, organization communication

The regression analysis results shows that role ambiguity has a negative insignificant relation with job performance with a $(\beta=-0.309)$ and $(p>0.05)$. The results reject the hypothesis. Role ambiguity has negative significant relationship with organization commitment with $(\beta=-.154)$ and $(\mathrm{P}=0.05)$ so it validate this hypothesis. Role ambiguity has insignificant negative relationship with organization communication with $(\beta=-.095)$ and $(p>0.05)$, so it rejects its hypothesis.

\section{H8: Role conflict effects job stress}

Role conflict has a positive significant relationship with job stress. The analysis shows that $(\beta=0.195)$ and $(p<0.05)$. The analysis accepted the H6.

H9: Role conflict effects organization communication, job performance, and job satisfaction

Results shows that role conflict has significance relationship with organization communication and job satisfaction with $(\beta=-.228),(\beta=-.280)$ and $(\mathrm{p}<0.05)$. Role conflict has negative but insignificant relationship with job performance with $(\beta=-.118)$ and $(p>0.05)$.

H9: Organization communication effects TOI

The analysis shows that organization communication has significant negative relationship TOI with $(\beta=-.168)$ and $(\mathrm{p}=0.05)$ so current result validate the hypothesis.

H10: Job performance effects TOI.

The analysis shows that job performance has significant negative relationship with TOI with $(\beta=-.319)$ and $(\mathrm{p}<0.05)$. So current result validate $\mathrm{H} 10$. 


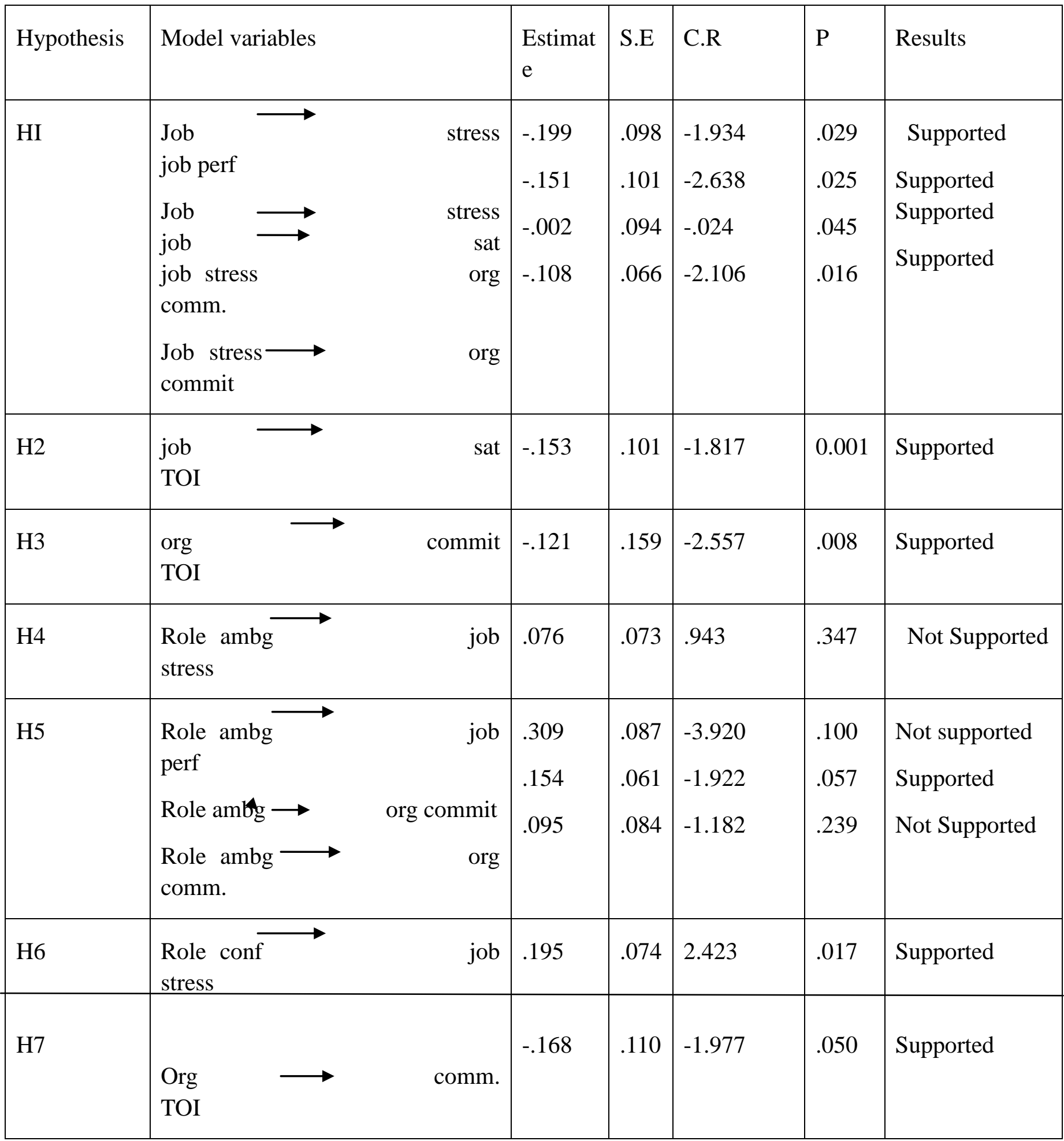




\section{Figure 2: structural Model Results}

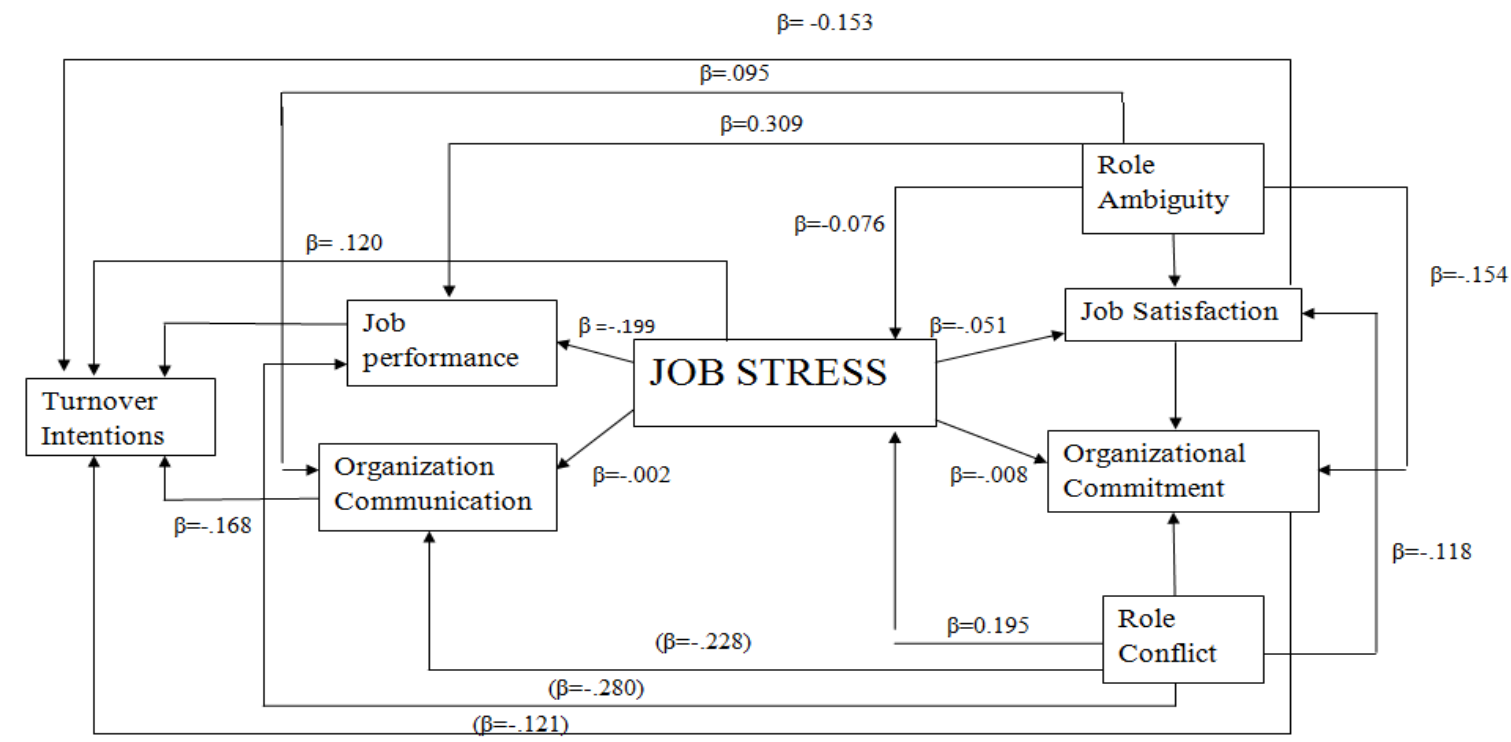

\section{Discussion}

One of the key contributions of this model was to supply a higher understanding of Job stress however job stress affects totally different variables. The present study developed to investigate the effect of job stress on the employees' productivity and effectiveness. Specifically, it investigates the effect of job stress in one of the major organizations of Bahawalpur. The study model posited that job stress arises as a result of role conflict and role ambiguity and effects structure commitment, organization communication, job performance, job satisfaction and turnover intention. The results counsel that every of those factors square measure influenced by job stress to differing degrees. In most cases, support was found for several, however not all of the direct effects. To decrease job turnover intention and minimize the prices related to it, employers ought to specialize in increasing structure commitment and job satisfaction and decreasing job stress, work-home conflict, and role conflict.

Paying additional attention to numerous structure characteristics particularly to those associated with social interactions with management and coworkers is also a fruitful. Findings indicate there square measure positive relationships between organization communication, structure commitment and job performance. Organization communication effects TOI Studies show that org. communication has a negative and significant relationship with Tithes finding suggests that firms ought to strengthen their communication channels and processes so as to extend their structure commitment and job performance of workers. We checked the impact of different variables on job stress i.e. Role ambiguity and role conflict. Studies show that Role ambiguity has a positive relationship with job stress, as role ambiguity increases, it give rise to stress and has an insignificant relationship. Studies show that as role ambiguity increases, it reduces job performance, organization commitment and 
organization communication, means it have a negative, but insignificant relationship with job performance and communication, where as significant with organization commitment.

Role conflict effects job stress and our Study prove that role conflict has a positive and significant relationship with job stress. Role conflict effects organization communication, job performance, and job satisfaction Studies show that role conflict has a negative significant relationship with organization communication, negative and insignificance with job performance and negative and significance relationship job satisfaction. In this study it was found that job stress was negatively related to job performance, and this result is consistent with the results gained by the majority of previous researchers. The positive relationship found in this study between role ambiguity and job stress. Job stress effects TOI. Studies show that job stress has a positive and insignificant relationship with turnover intention. The regression indicates there are positive relationships between organization communication, organizational commitment and job performance. This finding suggests that companies strengthen their communication channels and processes in order to strength their organizational commitment and job performance. Stress can bring undesirable impacts on employees through creating low organizational commitment and job dissatisfaction.

When sources of stress increase in job environment, job satisfaction reduces. So, job satisfaction has an important role in improving the performance of employees .Studies shows that job satisfaction has negative relation with turnover intentions, as job satisfaction will be greater, TOI will be lower. It has a significant relationship consequently, if there are discrepancies between individuals' desires and expectations and condition of their present jobs, negative thoughts and dissatisfaction arise at work. Some other variables were also tested and we found different results. it was found that Organizational commitment effects TOI Studies indicate that organization commitment has negative relation with turnover intention, as organization commitment increases, TOI decreases. It has an insignificant relationship. Some hypothesis was proved through the result of our study and some show insignificant relationship. We tried our best to consider all those variables which could support our result and hypothesis. We hope that our findings will play their major role to overcome all those factors which cause job stress and leads dissatisfaction of employees and enhance commitment and satisfaction of employees towards their organization. We also hope that managers will get major support through this study and will enhance their organization channels to communicate the role of employees effectively and will clear what they expect to them.

\section{Implications/Practical value}

Findings of this analysis have varied implications for each managers and workers of various organizations. The sager model seems to supply a viable structure for understanding the previous circumstances and consequences of job stress during a considerably operating atmosphere. The general patterns within the finding counsel that the job stress has very important consequences that area unit associated to employee's turnover. Lower stress ends up in higher job satisfaction that shows that job met expectations, and ultimately higher organization commitment. Higher performance and lower propensity to 
depart area unit related to higher job satisfaction and commitment to the organization. Chance of a corporation manager's to attenuate job stress seems related to falling the employees' role conflict and role ambiguity

An integrative model of stress that's probably relevant was represented by Beehr and Bhagat (1985). They counsel that stress may be a result of the supposed doubt in getting outcomes, supposed significance of those outcomes, and length. Stress was toughened owing to loss of management over getting most well-liked outcomes on the task (lack of expertise with work patterns, ambiguity of labor role, and lack of management over managing the impact of absence on personal relationships).

\section{Research directions}

A number of potential directions are recommended for future analysis on job stress in numerous organizations. 1st of all extra attention needed to spot, each governable and non-controllable antecedents of role conflict and role ambiguity. One most promising space is to target factors directly associated to the role of administration management (Jaworski et al., 1993), training, compensation and different potential factors and their belongings as antecedents of job stress. a further a part of study that wants thought is to search out out what ways ought to be adopted to decrease potential threats exhibit by job stress.

\section{References}

Abraham, R. (1999), "The impact of emotional dissonance on organizational commitment and intention to turnover", The Journal of Psychology, Vol. 133 No. 4, pp. 441-55.

Arnold, H.J. and Feldman, C.C. (1982), “A multivariate analysis of the determinants of job turnover”, Journal of Applied Psychology, Vol. 67 No. 3, pp. 350-60

Babin, B.J. and Boles, J.S. (1996), "The effects of perceived co-worker involvement and supervisor support on service provider role stress, performance, and job satisfaction", Journal of Retailing, Vol. 72 No. 1, pp. 57-75.

Babin, B.J., Boles, J.S., 1998. Employee behavior in a service environment: a model and test of potential differences between men and women. Journal of Marketing $62(2), 77-91$.

Bashaw, E.R. and Grant, S.E. (1994), "Exploring the distinctive nature of work commitment: their relationship with personal characteristics, job performance, and propensity to leave", Journal of Personal Selling and Sales Management, Vol. 14 No. 2, pp. 41-56.

Bluedorn, A.C. (1982), “A unified model of turnover from organizations”, Human Relations, pp. 135-53. 
Boshoff, C. \& Arnolds, C. (1995). Some antecedents of employee commitment and their influence on job performance. South African Journal of Business Management, 26 (4), 125-135.

Brown, S., Peterson, R.A., 1993. Antecedents and consequences of salesperson job satisfaction: meta-analysis and assessment of causal effects. Journal of Marketing Research 30 (1), 63-77. (in Hebrew). of Marketing Research, Vol. 23, pp. 153-63.

Bruck, C.S., Allen, T.D., Spector, P.E., 2002. The relation between work-family conflict and job satisfaction: a finer-grained analysis. Journal of Vocational Behavior 60, $336-353$.

Chen, C.F., 2006. Job satisfaction, organizational commitment, and flight attendants' turnover intentions: a note. Journal of Air Transport Management 12, 274e276.

Davy, J.A., Kinicki, A.J. and Scheck, C.L. (1991), "Developing and testing a model of survivor Van Breukelen, W., Van der Vlist, R. and Steensma, H. (2004), "Voluntary employee turnover: combining variables from the traditional turnover literature with the theory of planned behavior”, Journal of Organizational Behavior, Vol. 25 No. 7, pp. 893-914.

Day, D.V. \& Bedeian, A,G, (1995). Personality similarity and work-related outcomes among African-American nursing personnel: A test of the supplementary model of personenvironment congruence. Journal of Vocational Behaviour, 46, 55-70.

de Croon, E.M., Broersen, J., Blonk, R., Frings-Dresen, M., 2004. Stressful work, psychological job strain, and turnover: a 2-year prospective cohort study of truck drivers. Journal of Applied Psychology 89, 442-454.

Fisher, C.D. and Gittleson, R. (1983), "A meta-analysis of correlates of role conflict and ambiguity", Journal of Applied Psychology, Vol. 68, pp. 320-33.

Fry, L.W., Futrell, C.M., Parasuraman, A. and Chmielewski, M.A. (1986), “An analysis of alternative causal models of salesperson role perceptions and work related attitudes", Journal Carayon, P., 1993. A longitudinal test of Karasek's job strain model among office workers. Work \& Stress 7, 299-314.

Gilboa, S., Shirom, A., Fried, Y., \& Cooper, C. (2008). A meta-analysis of work demand stressors and job performance: Examining main and moderating effects. Personnel Psychology, 61(2), 227-271.

House, R.J. and Dessler, G. (1974), "The path-goal theory of leadership: some post hoc and a priori tests", in Hunt, J. and Arson, L. (Eds), Contingency Approaches to Leadership, Southern Illinois University Press, Carbondale, IL. 
Jex, S. M. (1998). Stress and job performance: Theory, research, and implications for managerial practice. Thousand Oaks, CA: Sage.

Johnston, M.W., Parasuraman, A., Futrell, C.M. and Black, W.C. (1990), “A longitudinal assessment of the impact of selected organizational influences on salespeople's organizational commitment during early employment”, Journal of Marketing Research, Vol. 27, August, pp. 333-44. Vol. 5 Nos 1/2, Cambridge, MA, pp. 164-70.

Joiner, T.A., Bartram, T. and Garreffa, T. (2004), "The effects of mentoring on perceived career success, commitment and turnover intentions", Journal of American Academy of Business, Abraham, R. (1999), "The impact of emotional dissonance on organizational commitment and intention to turnover”, The Journal of Psychology, Vol. 133 No. 4, pp. 441-55.

Kahn, R., Wolfe, D., Quinn, R., Snoek, J., Rosenthal, R., 1964. Organizational Stress: Studies on Role Conflict and Ambiguity. John Wiley, New York.

Kalbers, L.P. and Fogarty, T.J. (2005), “Antecedents to internal auditor burnout”, Journal of Managerial Issues, Vol. 17 No. 1, pp. 101-18.

Karatepe, O.M., Uludag, O., 2007. Conflict exhaustion, and motivation: a study of frontline employees in Northern Cyprus hotels. International Journal of Hospitality Management 26, 645-665.

Keinan, G. (1997), Stress Situations: Ways of Coping and Therapy, Prolog Press, Rosh Ha'ain (in Hebrew).

Keinan, G. (1997), Stress Situations: Ways of Coping and Therapy, Prolog Press, Rosh Ha'ain (inHebrew).

Kim, H.B., 1996. Perceptual mapping of attributes and preferences: an empirical examination of hotel $\mathrm{F} \& \mathrm{~B}$ products in Korea. International Journal of Hospitality Management 15, 373-391.

Lawler, E.E. (1990), High Involvement Management, Jossey-Bass, San Francisco, CA. Lefkowitz, J. (1994), "Sex-related differences in job attitudes and dispositional variables: now you see them", Academy of Management Journal, Vol. 37, pp. 323-49.

Mannheim, B., Baruch, Y. and Tal, J. (1997), “Alternative models for antecedents and outcomes of work centrality and job satisfaction of high-tech personnel", Human Relations, Vol. 50 No. 12, pp. 1537-61. 
Meijman, T.F., Mulder, G., 1998. Psychological aspects of workload. In: Drenth, Lin P.J.D., Thierry, H. (Eds.), Handbook of Work and Organizational Psychology, Work Psychology, vol. 2. Psychology Press, Hove, pp. 5-33.

Montgomery, D.C., Blodgett, J.G. and Barnes, J.H. (1996), "A model of financial securities salespersons' job stress”, The Journal of Services Marketing, Vol. 10 No. 3, pp. 21-38.

Morrow, P.C. (1993), The Theory and Measurement of Work Commitment, JAI, Greenwich, CT. Zaitman-Speiser, I. (2005), "On the relationship between performance levels, organizational Commitment, career commitment and employees' turnover: comparison between high-tech and low-tech organizations", PhD dissertation, Bar Ilan University, Ramat-Gan (in Hebrew)

Mueller, C.W., Wallace, J.E. and Price, J.L. (1992), "Employee commitment: resolving some issues", Work and Occupations, Vol. 19 No. 3, pp. 211-36.

Mueller, C.W., Wallace, J.E. and Price, J.L. (1992), "Employee commitment: resolving some issues", Work and Occupations, Vol. 19 No. 3, pp. 211-36.

Near, J.P. (1989), “Organizational commitment among Japanese and US workers”, Organization Studies, Vol. 10 No. 3, pp. 281-300.

Noone, B.M., 2008. Customer perceived control and the moderating effect of restaurant type on evaluations of restaurant employee performance. International Journal of Hospitality Management 27, 23-29.

Noone, B.M., 2008. Customer perceived control and the moderating effect of restaurant type on evaluations of restaurant employee performance. International Journal of Hospitality Management 27, 23-29.

Porter, L.W. and Lawler, E.E. (1968), Managerial Attitudes and Performance, Irwin-Dorsey, Homewood, IL Rees, D.W. (1995), "Work-related stress in health service employees", Journal of Managerial Psychology, Vol. 10 No. 3, pp. 4-11.

Ralston, D.A., Westman, M., Vollmer, G., Tang, M., Wan, P., Van Deusen, C.A., 2002. Are work stressor relationships universal? A nine-region examination of role stressors, general self-efficacy, and burnout?. Journal of International Management 8, 163-197.

Rizwan, M., Shahid, M., Shafiq, H., Tabassum, S., Bari, R. \& Umer, J. (2013) Impact of Psychological Factors on Employee Turnover Intentions, International Journal of Research in Commerce, Economics and Management, 3(3), 63-69 
Fisher, R.T. (2001), "Role stress, the type A behavior pattern, and external auditor job satisfaction and performance", Behavioral Research in Accounting, Vol. 13, pp. 143-69.

Patten, D.M. (1995), "Supervisory actions and job satisfaction: an analysis of differences between large and small public accounting firms", Accounting Horizons, Vol. 9 No. 2, pp. 17-28.

Cohen, J., Cohen, P., West, S. G., \& Aiken, L. S. (2003). Applied multiple regression correlation analysis for the behavioral sciences (3rd ed.). Mahwah, NJ: Erlbaum.

Cohen, J., Cohen, P., West, S. G., \& Aiken, L. S. (2003). Applied multiple regression correlation analysis for the behavioral sciences (3rd ed.). Mahwah, NJ: Erlbaum.

Mathieu, J.E. and Zajac, D.M. (1990), "A review and meta-analysis of the antecedents, correlates, and consequences of organizational commitment”, Psychological Bulletin, Vol. 108, pp. 171-94.

Meyer, J.P. (1996), “Affective, continuance, and normative commitment to the organization: examination of construct validity", Journal of Vocational Behavior, Vol. 49

No. 3, pp. 252-76.

Rizwan, M., Tariq, M. A., Hussain, S., Rashid, R. M., Hussain, M. S., Khawar, I., H. (2013) Antecedents of Job Stress and Its impact on Job Satisfaction, Asian Journal of Empirical Research, 3(2), 175-190

Montgomery, D.C., Blodgett, J.G. and Barnes, J.H. (1996), “A model of financial securities sales persons' job stress", The Journal of Services Marketing, Vol. 10 No. 3, pp. 21-34.

Netemeyer, R.G., Boles, J.S., McKee, D.O. and McMurrian, R. (1997), “An investigation into the antecedents of organizational citizenship behaviors in a personal selling context", Journal of Marketing, Vol. 61 No. 3, pp. 85-98

Stamper, C.L., Johlke, M.C., 2003. The impact of perceived organizational support on 


\section{Macrothink \\ International Journal of Learning \& Development

the relationship between boundary spanner role stress and work outcomes.

Journal of Management 29, 569-588.

Sullivan, S.E. and Bhagat, R.S. (1992), "Organizational stress, job satisfaction and job performance: where do we go from here?”, Journal of Management, Vol. 18 No. 2, pp. 353-74.

Weisner, S. (2003), “A model linking the individual's personality, job stresses and types of organizational commitment", PhD dissertation, Ramat-Gan, Bar Ilan University, Sager, J.K. (1990), "Reducing sales manager job stress", The Journal of Consumer Marketing, Vol. 7 No. 4, pp. 5-14.

Whitener, E. (2001), "Do high commitment human resource practices affect employee commitment? A cross-level analysis using hierarchical linear modeling", Journal of Management, Vol. 27 No. 5, pp. 515-35.

Williams, C., 2003. Sky service: the demands of emotional labour in the airline industry. Gender, Work and Organization 10, 513e550.

Williams, L.J. and Hazer, J.T. (1986), “Antecedents and consequences of satisfaction and commitment in turnover models: a reanalysis using latent variable structural equation methods", Journal of Applied Psychology, Vol. 71 No. 2, pp. 219-31. 